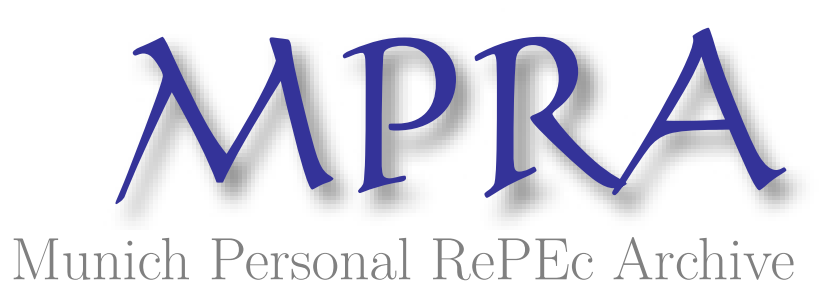

\title{
Macroeconomic Determinants of Workers' Remittances and Compensation of Employees in Sub-Saharan Africa
}

\author{
Adenutsi, Deodat E. \\ University of Stellenbosch
}

9 February 2013

Online at https://mpra.ub.uni-muenchen.de/60620/

MPRA Paper No. 60620, posted 15 Dec 2014 05:47 UTC 


\title{
The Journal of Developing Areas \\ Volume $48 \quad$ No. $1 \quad$ Winter 2014 \\ MACROECONOMIC DETERMINANTS OF WORKERS' \\ REMITTANCES AND COMPENSATION OF EMPLOYEES IN SUB-SAHARAN AFRICA
}

\author{
Deodat E. Adenutsi \\ Faculty of Economic and Management Sciences \\ Graduate School of Business \\ University of Stellenbosch \\ Republic of South Africa
}

\begin{abstract}
In this paper, an attempt has been made to identify the macroeconomic determinants of migrant remittances received in SubSaharan Africa (SSA) at the disaggregated level. The underlying motivation is that, given their unique characteristics, permanent and temporary migrants are likely to respond differently to macroeconomic conditions in migrant-host countries and their native or migrant-home countries. For the empirical analysis, the system Generalized Method of Moments (GMM) approach was used to estimate a dynamic panel-data model involving 36 SSA countries over the period, 1980-2009. It was found that the inflows of compensation of employees and workers' remittances to SSA are influenced by host-country macroeconomic conditions in a similar way, whereas these two forms of remittances are driven by contrasting home-country macroeconomic conditions. Remittances from permanent migrants are less altruistic than remittances from temporary migrants. To attract higher remittances on a more permanent basis, the implementation of stable macroeconomic and pro-growth policies are inevitable in laborexporting SSA countries.
\end{abstract}

JEL Classification: C23, E42, F22, F24, J33

Keywords: Workers' Remittances, Compensation of Employees, Money, Migrant, SSA

Corresponding Author's Email: deo.adenutsi@gmail.com

\section{INTRODUCTION}

According to the United Nations (2009), Europe leads as the main host of migrants with 32.6 percent of international migrant stock, followed by Asia (28.6 percent), North America (23.4 percent), Africa (9 percent), Oceania (2.8 percent) and Latin America (2.4 percent). Clearly, the net international migration trend is South-North, given the widening income gap and contrasting working conditions between the industrialized North and the impoverished South. Although labor-exporting countries may suffer from brain-drain, these low-income countries have been benefiting directly by way of international remittances. This could be the most obvious explanation as to why developing countries are the main destinations of migrant remittances with the industrialized world maintaining its status as the main source of remittance flows ${ }^{1}$. It is also not surprising that remittances have, over the past three decades, emerged strongly as an alternative source of development finance in many developing countries.

In recent years, official remittances alone surpass Official Development Assistance (ODA) and Foreign Direct Investment (FDI) in India, China, Mexico, Philippines, Lesotho, and in many other countries in Latin America and the Caribbean and South Asia. ${ }^{2}$ Official migrant remittances received by developing countries reached US $\$ 116$ billion in 2003 representing more than 1.5 percent of their gross domestic product (GDP) ${ }^{3}$. In 2004, migrant remittances of US $\$ 126$ billion became the second most important source of foreign exchange earnings to developing countries (World Bank, 2006). This was the year in which FDI to developing 
countries stood at US\$165 billion with gross ODA amounting to US\$79 billion (World Bank, 2006). Recorded migrant remittances received by developing countries rose to US $\$ 194.2$ billion in 2005, reaching an all-time high of US\$336 billion in 2008 before plummeting to US\$316 billion in 2009, in response to the global financial crisis of 2007-2009 (World Bank, 2010). Still, the relatively superior importance of migrant remittances over other capital inflows in developing countries, with respect to size, growth rate and stability, remains unchanged over the past four decades as the decline in 2009 is only the second after the first was recorded in 1985.

Despite the general positive growth trend in migrant remittances, and also having being a major exporter of migrants, it is puzzling that SSA as a sub-region has remained the least recipient of official migrant remittances in terms of actual volume and per capita (see Figure A2 in the Appendix), a situation that raises a lot of questions. Is there anything macroeconomic policy environment can do to increase official remittances received by SSA? Which of the components of migrant remittances do macroeconomic factors most affect, and in which direction? In other words, do macroeconomic factors impact differently on compensation of employees and workers' remittances? These pertinent questions are the motivation for verifying if macroeconomic factors have any distinctive impact on workers' remittances and compensation of employees as separate components of migrant remittances in SSA. Understanding the macroeconomic factors underlying the inflows of workers' remittances and compensation of employees is crucial for the formulation of a relevant, effective and integrated policy towards mobilizing optimal remittances in SSA. This is because each of these components of remittances has its own distinct features. For instance, workers' remittances are the funds transferred by migrants who have settled outside their home countries for at least 12 months, and hence, are more associated with permanent migration; whilst compensation of employees is more associated with temporary migration as it comprises funds transferred from migrants with less than 12 months' settlement outside their home countries. In order to find answers to the questions as posed above, 36 SSA countries for which relevant balanced data over the past three decades, 1980-2009 exists, were sampled for the empirical analysis. The remaining part of this paper is organized as follows. Some stylized facts on the trend and magnitude of remittance inflows are provided in Section 2. This is followed by the literature review and theoretical framework in Section 3. Section 4 presents the empirical model as well as the methodological approach. The empirical results are presented and discussed in Section 5. Conclusions, policy implications and recommendations follow in Section 6.

\section{REMITTANCE FLOWS TO SSA: SOME STYLIZED FACTS}

Figure 1 shows the composition and the level of dependency on migrant remittances in the 36 SSA countries sampled for the empirical analysis in this study. An important observation from Figure 1 is that, migrant remittances received by SSA are largely dominated by workers' remittances irrespective of whether or not a country is a high-remittance dependent or lowremittance dependent. Only four countries, (Lesotho, Botswana, Congo and Tanzania), rely more on compensation of employees than on workers' remittances. Apart from Congo, these are all countries in the southern part of the sub-region, members of the Southern African Development Community (SADC), and neighbours of the Republic of South Africa. This underscores the fact that temporary migration is more common among countries in the southern part of SSA than elsewhere within the sub-region. It is likely that, unlike nationals of other parts within the sub- 
region, nationals of SADC countries might find it relatively easier, cheaper and more convenient to migrate temporarily to neighboring South Africa, the economy that can be described as 'industrialized' based on the continental and sub-regional standards.

FIGURE 1. COMPOSITION AND DEPENDENCY OF SSA COUNTRIES ON MIGRANT REMITTANCES, 1980-2009

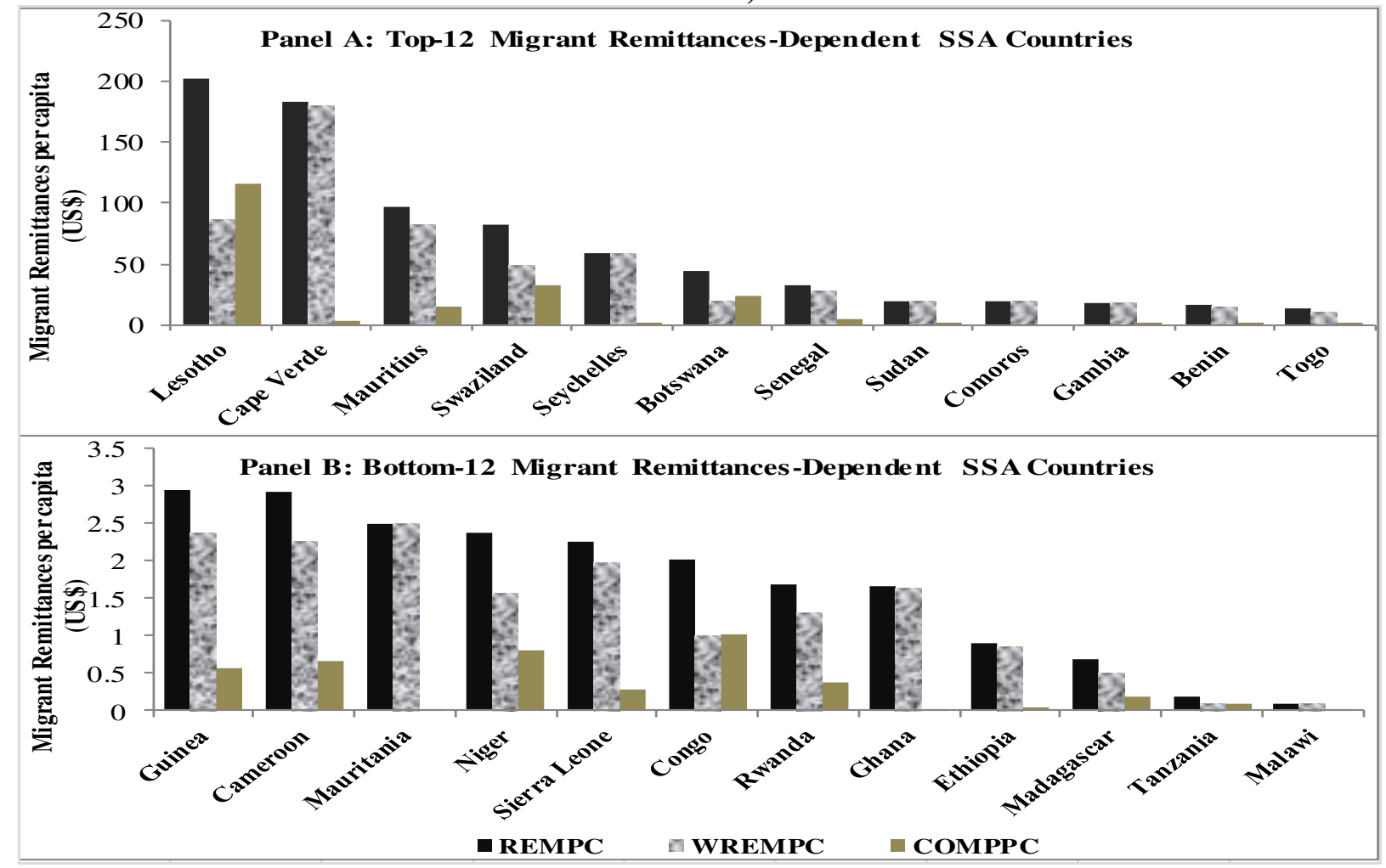

Source: Compiled by the author based on sources cited in Table A2 covering only the 36 sampled countries.

Note: REMPC, WREMPC and COMPC denote migrant remittances per capita, workers' remittances per capita and compensation of employees per capita respectively.

In terms of income status, there is no distinctive pattern of dominance in either category as relatively high-income countries such as Cameroon and Congo are listed among the least migrant remittance-dependents just as other high-income countries like Seychelles, Cape Verde, Mauritius and Botswana are listed among the high migrant remittance-dependents. It is shown in Figure 1 Panel A that, with the exception of Cape Verde, SADC countries viz. Lesotho, Mauritius, Swaziland, Seychelles and Botswana, dominate the top-6 migrant remittancedependent countries. The remaining top-12 migrant remittance-dependents (Cape Verde, Senegal, Sudan, Gambia, Benin and Togo) are predominantly West African countries. Comoros is the only country from the eastern part of the sub-region listed among the top-12 remittancedependents. The geographical background of the bottom-third of migrant remittance-dependent countries is quite heterogeneous, but with West African countries dominating with five countries (Guinea, Mauritania, Niger, Sierra Leone, and Ghana) out of the 12 in the bottom category. Central and Eastern Africa has four countries (Cameroon, Congo, Rwanda, and Ethiopia) with 
SADC having three of its members (Madagascar, Tanzania and Malawi) among countries with least dependency on migrant remittances. Again, Panel B is dominated by countries with relatively large geographical size such as Cameroon, Mauritania, Niger, Congo, Madagascar and Tanzania. Despite this, Guinea, Sierra Leone, Rwanda and Malawi, with relatively small geographical sizes, are also included in this category of countries with the least dependency.

Thus, with reference to SSA, migrant remittances flow to both high-income and lowincome SSA countries and these remittances do not depend necessarily on the geographical size or location of the country. This implies that some macroeconomic policies must be responsible for the changing and unequal flow of migrant remittances received by SSA as a sub-region.

Literature suggests the inclusion of both home-country and the host-country factors in identifying the macroeconomic factors that explain variations in migrant remittances received by developing countries (see Section 3). Most cross-country empirical studies on macroeconomic determinants of remittances tend to use the United States of America (USA) as the migrant-host country. A few other authors including Elbadawi and Rocha (1992), Lianos (1997), and BouhgaHagbe (2004) made attempts at using countries other than the USA as the migrant-host nation in country-specific studies at the macro-level, with the focus on bilateral remittances. In the case of SSA countries, however, majority of the migrants, at least 70 percent, migrate to reside in other SSA countries. ${ }^{4}$ This makes the pattern of migration among citizens of SSA unique compared to the rest of the world. Notwithstanding the fact that SSA still serves as the main host of its 'own migrants', the most important source of international remittances to the various SSA countries is the SSA migrants residing in countries outside the sub-region (Ratha and Shaw, 2007; Bollard et al., 2010). In Table 1 a list of the 36 sampled SSA countries and the main hosts of their citizens living outside SSA is presented. 


\section{TABLE 1. HOST COUNTRIES OF SSA MIGRANTS RESIDENT OUTSIDE SSA}

$\begin{array}{cllcll}\text { Country Code } & \text { Country Name } & \text { Non-SSA Host-Country } & \text { Country Code } & \text { Country Name } & \text { Non-SSA Host-Country } \\ 1 & \text { Benin (BEN) } & \text { France (FRA) } & 19 & \text { Mali (MLI) } & \text { France (FRA) } \\ 2 & \text { Botswana (BSW) } & \text { Great Britain (GBR) } & 20 & \text { Mauritania (MRT) } & \text { France (FRA) } \\ 3 & \text { Burkina Faso (BFA) } & \text { Pakistan (PAK) } & 21 & \text { Mauritius (MRS) } & \text { France (FRA) } \\ 4 & \text { Cameroon (CAM) } & \text { France (FRA) } & 22 & \text { Mozambique (MZQ) } & \text { Portugal (POR) } \\ 5 & \text { Cape Verde (CPV) } & \text { Portugal (POR) } & 23 & \text { Namibia (NAM) } & \text { Great Britain (GBR) } \\ 6 & \text { Comoros (COM) } & \text { France (FRA) } & 24 & \text { Niger (NGR) } & \text { Germany (GER) } \\ 7 & \text { Congo Republic (CON) } & \text { France (FRA) } & 25 & \text { Nigeria (NIG) } & \text { United States of America (USA) } \\ 8 & \text { Côte d'Ivoire (CIV) } & \text { France (FRA) } & 26 & \text { Rwanda (RWA) } & \text { Belgium (BEL) } \\ 9 & \text { Ethiopia (ETH) } & \text { United States of America (USA) } & 27 & \text { São Tomé \& Príncipe (ST\&P) Portugal (POR) } \\ 10 & \text { Gabon (GAB) } & \text { France (FRA) } & 28 & \text { Senegal (SEN) } & \text { France (FRA) } \\ 11 & \text { Gambia (GAM) } & \text { Spain (ESP) } & 29 & \text { Seychelles (SEY) } & \text { Great Britain (GBR) } \\ 12 & \text { Ghana (GHA) } & \text { United States of America (USA) } & 30 & \text { Sierra Leone (SLE) } & \text { United States of America (USA) } \\ 13 & \text { Guinea (GUI) } & \text { Great Britain (GBR) } & 31 & \text { South Africa (RSA) } & \text { Great Britain (GBR) } \\ 14 & \text { Guinea-Bissau (GBS) } & \text { Portugal (POR) } & 32 & \text { Sudan (SUD) } & \text { Saudi Arabia (SAU) } \\ 15 & \text { Kenya (KEN) } & \text { Great Britain (GBR) } & 33 & \text { Swaziland (SWZ) } & \text { Great Britain (GBR) } \\ 16 & \text { Lesotho (LSO) } & \text { Germany (GER) } & 34 & \text { Tanzania (TNZ) } & \text { Great Britain (GBR) } \\ 17 & \text { Madagascar (MAD) } & \text { France (FRA) } & 35 & \text { Togo (TOG) } & \text { France (FRA) } \\ 18 & \text { Malawi (MLI) } & \text { Great Britain (GBR) } & 36 & \text { Uganda (UGA) } & \text { Great Britain (GBR) }\end{array}$

Source: Author's compilation from Parson et al. (2007) according to the number of SSA migrants resident abroad.

A key feature in the pattern of SSA international migration as shown in Table 1 is that most of its migrants reside in Europe rather than in the Americas. Factors such as distance or travelling cost, geopolitical history or former colonial relationship, lingual Franca and religious affinities underlie the choice of destination of SSA international migrants. For instance, international migrants from Francophone SSA countries such as Benin, Cameroon, Comoros, Congo, Côte d'Ivoire, Mauritania and Senegal are hosted by France with which they have a common language. These SSA countries were also colonized by France in the past. The same trend is easily visible in the case of migrants from Portuguese-speaking countries (Cape Verde, Mozambique, São Tomé and Príncipe and Guinea-Bissau) and migrants from English speaking countries such as Kenya, Botswana, Malawi, Namibia, South Africa, and Uganda. Regarding religious affinities, SSA migrants from Muslim-dominated countries such as Burkina Faso, Benin, Niger and Sudan are commonly resident in countries like Jordan, Pakistan and Saudi Arabia with common religion dominance.

It can be seen in Table 1 that France (12), Great Britain (10), United States of America (4), Portugal (4) and Germany (2) are the first-choice hosts of SSA migrants outside the subregion. This implies that Europe leads as the main host of SSA international migrants ${ }^{5}$. Belgium, Pakistan, Saudi Arabia, and Spain are also the leading host countries for migrants from Rwanda, Burkina Faso, Sudan, and Gambia respectfully. Clearly, using USA as the main host of SSA migrants in an empirical study aimed at analyzing the determinants of migrant remittance inflows in SSA should not be considered appropriate.

\section{LITERATURE REVIEW AND THEORETICAL FRAMEWORK}

\section{Literature Review on Macroeconomic Determinants of Remittances}

Contributing to the debate initiated by Lucas and Stark (1985) on the determination of remittances, Russell (1986), Elbadawi and Rocha (1992), Lianos (1997), Vargas-Silva and 
Huang (2006), and Coulibaly (2009) contend that macroeconomic performance can affect the flow of remittances. The altruistic theory of remittances from the macroeconomic perspective suggests that remittances are higher when negative shocks and high frictions in the labor market occur in low-income countries, creating an incentive for the active population to migrate to the industrialized world in search of higher-wage jobs ${ }^{6}$. Given an existing strong social tie between a migrant and his/her family left behind, the theory of pure altruism predicts that the migrant will remit more funds to his/her family back home during severe economic hardships in the home country and reduce both the amount and the frequency of funds transferred during economic boom at home. Accordingly, with a decrease in real per capita income (or during economic recession), inflation episodes, exchange rate instability and constraints in the credit market of a typical labor-exporting country, the migrant is expected to remit more money and to remit more regularly to his/her family back home (Wahba, 1991; Vargas-Silva and Huang, 2006). This suggests that higher growth in real per capita GDP in the labor-exporting country relative to the income growth rate in the industrialized labor-importing country should impact negatively on remittance inflows to developing countries (Swamy, 1981; Brown, 1997).

Even though the above expositions imply from pure altruistic theory that migrant remittances should flow in a countercyclical pattern as they respond to negative income shocks in remittance-recipient countries, empirical evidence has been mixed. For instance, whilst ElSakka and McNabb (1999), Bouhga-Hagbe (2006), Yang and Choi (2007), and Singh et al. (2010) provide evidence on the countercyclical property of remittances, Higgins et al. (2004), Aydaş et al. (2004) and Adenutsi et al. (2012) find that the pattern of remittance flows is procyclical as it tends to rise with increased GDP per capita and higher growth rate in remittance-receiving countries. Sayan (2006) and Adenutsi et al. (2011) also find that in most cases remittances are either acyclical or procyclical.

The theory of self-interest motive underlying the flow of migrant remittances, which is closely synonymous with the portfolio choice theory, implies that as economic conditions in labor-exporting countries improve relative to the labor-importing country, more remittances are received in the labor-exporting countries through higher migrant savings and investment (Russell, 1986; Wahba, 1991; Coulibaly, 2009). For instance, increased real per capita income in a migrant's native country is considered by the migrant as a positive signal of higher return on investment at home. Also, with higher economic prospects at home, a migrant, who hitherto had lost confidence at home and decided never to return home, could now consider returning home in the future. Such a migrant can increase his/her savings at home. It is for this reason that a higher real deposit interest rate of a migrant's home country relative to the migrant's host country is expected to impact positively on remittance inflows in the labor-exporting country. In like manner, as the national currency of a migrant's home country becomes stronger and stable domestically (low inflation) and internationally (exchange appreciation), the migrant may regain his/her confidence in his/her home country and, consequently, remit more funds home for the commencement of income-generating projects.

From a theoretical viewpoint, Lucas and Stark (1985) again argue that remittances can be driven by mixed motives rather than pure altruism and pure self-interest. This is most likely to be the case at the macroeconomic level where it is apparent that altruistic and self-interest theories underlying remittance flows are not mutually exclusive. It is, therefore, not surprising that although, theoretically, remittances can be analyzed from the altruistic and portfolio perspectives at the micro-level, virtually in all the macro-level studies on determinants of remittances, 
economic models are formulated from the mixed motive viewpoint, which involves a combination of pure altruistic motive and pure self-interest motive.

Various empirical studies including those of Elbadawi and Rocha (1992), Lianos (1997), Aydaş et al. (2004), Freund and Spatafora (2005), Gupta (2005), Schrooten (2005), Vargas-Silva and Huang (2006) and Singh et al. (2010) show that size of migrant stock, host-country versus home-country income gap, exchange rate fluctuations, deposit interest rates; political risk, access to international money transfer facilities and the economic conditions in migrant-host countries affect the volume and frequency of remittance flows. As to whether or not a migrant may remit through the formal or an informal money transfer channel, the level of financial development as reflected in the cost of funds transfer, the existence or absence of dual exchange rate at home, availability of financial infrastructure and innovative products, in especially labor-exporting countries, play an important role.

\section{Theoretical Framework}

Drawing lessons from Lucas and Stark (1985) and in the spirit of Vargas-Silva and Huang (2006), an optimal control theoretical framework designed to analyze the dynamics of remittance inflows was developed in this study. In this framework, a representative migrant maximizes his/her 'lifetime' consumption and transfers to his/her family at home based on his/her income constraint, 'initial divergence' constraint and 'impetus effect' constraint. The utility function has a composite consumption goods and transfers (remittances) as its elements. The income constraint reflects the fact that the migrant's total disposable income must be equal to the total expenditure on his/her current consumption of composite goods, transfers (i.e. remittances) and financial asset holdings. Although it is assumed that the holding of financial assets is a 'residual' activity by the migrant because he/she aims at returning home after some time ${ }^{7}$, financial asset holdings might enter the migrant's utility function directly. The initial divergence constraint highlights the initial differences in the migrant's home-country and the host-country conditions. It is essentially a total wealth constraint. The 'impetus effect' constraint suggests that the total amount of funds transferred is dependent upon the prevailing economic conditions and regulatory environment in the migrant's home country. The transversality conditions were imposed to reflect the fact that no household or individual can be in a 'ponzi-game' situation. In other words, no one can continue borrowing perpetually without loan repayment. That is, at the terminal stage, the migrant must repay all his/her debt. For optimality in consumption, the individual dies with no savings.

The steady state solution to the model using optimal control technique reveals the quantity of composite goods and the amount of fund transfers (remittances) that the individual migrant chooses at the steady state to maximize his/her utility and the variables that influence such a decision. With these, the explicit inter-temporal equilibrium relationships between the inflows of remittances and other relevant macroeconomic conditions at home and abroad are established.

Using a two-period scenario, Vargas-Silva and Huang (2006) model the inflow of remittances to developing countries under the assumptions that period one represents an initial stage of international migration of an individual, typically from a less developed country (the home country) to a more developed country (the host country). During this period, the individual (the migrant) does not migrate with his/her direct dependants (family). Thus, the economically 
active migrant resides in a relatively industrialized country where he/she is engaged in anincome-generating economic activity whilst his/her dependants continue to live in his/her lowincome native (home) country. In this context, the utility of the migrant depends on his/her personal consumption in the host country $\left(C_{f}\right)$ and the consumption of his/her family $\left(C_{h}\right)$ living his/her native country. Accordingly, Vargas-Silva and Huang (2006) specify that the utility function of the migrant in the initial period of migration is given as $U\left(C_{f}, C_{h}\right)$ with $U_{1}>0$, $U_{11}<0, U_{2}>0, U_{22}<0$; and under the assumption that utility is additively separable ${ }^{8}$. The consumption expenditure of the migrant's household living at home is dependent upon the income and remittances received $(\phi r)$ with $\phi$ which is the cost of transferring funds from the host country to the home country being of the form, $\phi \leq 1$. This implies that although a migrant remits $r$ dollars back home, only a fraction of this amount $\phi r$ is received by his/her family.

The income received by the migrant's household living at home is made up of two components and given as $Y_{h}+\gamma Y_{h}$ with $\gamma$ capturing the relationship between the economic conditions in the migrant's native country and the average income earned by his/her family living at home. $Y_{h}$ is the fraction of the household income that is not susceptible to changes in the macroeconomic conditions of the home country, whilst $\gamma Y_{h}$ is the part of the household income that is predisposed to changes in macroeconomic environment of the home country. It is assumed that $\gamma \geq 0$ which implies that an improvement in the economic conditions of the home country is associated with an improvement in the household income, even though the magnitude of $\gamma$ may differ across households. The consumption of the migrant's household living at home is given by $C_{h}\left(\left(Y_{h}+\gamma Y_{h}\right), \phi r\right)$. This consumption function is additively separable with $C_{h_{1}}>0, C_{h_{2}}>0, C_{h_{11}}<0$ and $C_{h_{22}}<0$. Likewise, the income of the migrant is in the form $y_{f}+\eta Y_{f}$ such that $\eta$ reflects the relationship between the economic conditions in the host country and the income the migrant earns in the host country.

The income constraint of the migrant during this first/initial period can, thus, be given as $y_{f}+\eta Y_{f}=C_{f}+r+s$ in which case $\eta \geq 0$ with $r$ being the proportion of the migrant's disposable income which he/she remits home, whilst $s$ represents the fraction of migrant's income saved in the home country. Here again, $y_{f}$ is the portion of the migrant's disposable income in the initial stages that is not susceptible to varying macroeconomic conditions of the host country. Similarly, $\eta Y_{f}$ is the portion of household income that is susceptible to changes in the economic condition of the host country $\left(Y_{f}\right)$.

During the second period (i.e. at the latter stages) of migration, the migrant's household migrates to a foreign industrialized country, often, joining the migrant in his/her host country ${ }^{9}$. If this assumption holds, then the optimization migrant problem is given as follows:

$$
\begin{aligned}
& \operatorname{Max} U\left(C_{f}, C_{h}\right)+\psi V\left(C_{z}\right) \\
& \{C, r, s\}
\end{aligned}
$$

subject to

$$
y_{f}+\eta Y_{f}=C_{f}+r+s
$$

and 


$$
C_{z}=y_{z}+\eta Y_{z}+(1+i) s
$$

where $V\left(C_{z}\right)$ denotes the utility from second period consumption so that $V_{1}>0$ and $V_{11}<0, \psi$ is a discount factor, $i$ is the interest rate (intuitively the deposit rate) of the home country, with $y_{z}$ and $Y_{z}$ having similar interpretations to $y_{f}$ and $Y_{f}$ but for the second period. Finding the firstorder conditions of this problem yields Equations (4) and (5):

$$
\begin{aligned}
& U_{1}=\psi V_{1}(1+i) \\
& \phi U_{2} C_{h_{r}}=\psi V_{1}(1+i)
\end{aligned}
$$

From Equations (4) and (5), it is possible to derive $r$ with respect to host country income $\left(Y_{f}\right)$ as shown in Equation (6) below:

$$
\frac{\partial r}{\partial Y_{f}}=\frac{\eta \psi U_{11} V_{11}(1+i)^{2}}{D} \geq 0
$$

where $D$, the determinant of the matrix of the second derivatives, is $D=U_{11} \psi V_{11}(1+i)^{2}+\phi^{2} \psi V_{11}(1+i)^{2}\left[U_{22} C_{h_{r}}+U_{2} C_{h_{r r}}\right]+U_{11} \phi^{2}\left(\left(C_{h_{r}}\right)^{2} U_{22}+C_{h_{r r}} U_{2}\right)>0$ for a maximum (Vargas-Silva and Huang, 2006). The central implication of Equation (6) is that an improvement in the economic conditions of the host country positively affects remittance flows from the host country to the migrant's home country. This is so because an increase in $Y$ implies improvements in economic conditions in host country which enable a migrant to remit more as $\eta \geq 0$; given that households spend their incomes on normal goods. In equation (7), it is also shown that an improvement in the economic conditions of the migrant's home country is associated with a decrease in remittance inflows in the remittance-receiving country.

$$
\frac{\partial r}{\partial Y_{h}}=(-)\left[\frac{\phi \gamma U_{22} C_{h_{r}} C_{h_{y_{h}}}\left[U_{11}+\psi V_{11}(1+i)^{2}\right]}{D}\right] \leq 0
$$

Impliedly, Equation (7) is non-positive when a migrant is remitting for altruistic purposes. Under this assumption, the migrant remits fewer funds to his/her family in the home country because the target household is better off $\gamma \geq 0$. Vargas-Silva and Huang (2006) prove that changes in remittances as a result of changes in the rate of interest in the host country could have two contrasting effects for which reason the sign of Equation (8) is indeterminate unless further assumptions are made.

$$
\frac{\partial r}{\partial i}=\left[\frac{-\psi U_{11}\left[V_{1}+V_{11}(1+i) s\right]}{D}\right]
$$

Thus, from Equation (8), on one hand, if there is a higher real rate of interest on deposits in the host country a rational migrant who is driven by a non-altruistic motive may reduce the amount of funds remitted to his/her home country and increase his/her savings in the host country. On the other hand, if real deposit interest rate in the host country increases, a migrant can now consume more in the future and since remittances form part of the consumption basket of the consumer, during the second period, funds remitted to the home country may increase. 
However, a typical non-altruistic SSA migrant is more likely to react more to changes to real interest rate in his/her home country than in the host country, the reason being that the rate of inflation in a migrant host-country is likely to be lower than the rate recorded in his/her home country, making real deposit rates lower and more erratic at home than abroad. Apart from this, migrants under implicit social contract would still be compared forcibly to remit home, irrespective of changes in the returns on financial assets in their respective host countries. With higher deposit rate at home, migrants with the intention of returning home after some time may be motivated to remit through banks and other money deposit institutions or Money Transfer Operators (MTOs) within the formal financial sector. Higher real interest rates on deposits at home are an indication of improved financial sector development through competition and risk diversification. In other words, local banks in the migrant home country are likely to mobilize more private funds in the form of remittances from migrants living abroad if real deposit rates are positive and attractive. Accordingly, in an attempt to respond to what macroeconomic policy SSA countries must implement to attract higher inflow of migrant remittances through the official channels, the role of the domestic financial sector and, for that matter, the level of real deposit interest rate in the home countries should be more imperative. This is why in the presence of the same level of deposit interest rates in the host-country (in this case France) countries like Benin, Comoros, Mauritius, Senegal and Togo received more official remittances than their compatriots like Cameroon, Congo, Madagascar and Mauritania notwithstanding the fact that France is the leading host of the migrants from these SSA countries. Thus, the use of home-country deposit interest rate rather than interest rate differential between the host country and the home country is the fundamental modification made to the Vargas-Silva and Huang theoretical framework.

\section{EMPIRICAL MODEL AND METHODOLOGICAL APPROACH}

The empirical model of this study is based on an extended Vargas-Silva and Huang (2006) theoretical framework within an analytical framework of a dynamic panel-data estimation technique of Blundell and Bond (1998) system Generalized Method of Moment (GMM). Equation (9) represents the general dynamic panel-data model.

$$
R_{i t}=\alpha_{i}+\rho R_{i, t-l}+x_{i t}^{\prime} \beta+\varepsilon_{i t}
$$

where the residuals $\left(\varepsilon_{i t}\right)$ are white noise such that $\varepsilon_{i t} \sim N\left(0, \sigma_{\varepsilon}^{2}\right), \alpha_{i} \sim$ i.i.d $\left(0, \sigma_{\alpha}^{2}\right)$ and $\rho$ is a scalar such that $|\rho|<1 ; i=1,2,3, \ldots ., N$ is an index for individual sampled SSA countries, implying $N=36 ; t=1,2,3, \ldots, T$ is an index for time-variant periods, in this case, years, so that $T=30$ for the overall-study period, 1980-2009. The endogenous variable $R$ is a measure of remittances either as workers' remittances per capita (WREMPC) or compensation of employees per capita (COMPPC). $x_{i t}^{\prime}$ is a row vector of explanatory variables excluding the lagged dependent variable with the dimension $k$ where $k=n \times 1$ and $n$ is the number of exogenous variables. $R_{i, t-l}$ is included as an explanatory variable so as to capture the theoretical conviction of dynamic effects of remittance inflows which suggests that migrant remittances could either decay or decrease in value overtime, often by the second-generation as family and social ties become weak (Lucas and Stark, 1985; Merkle and Zimmermann, 1992; Glytsos, 1997). 
The explanatory and not strictly exogenous variables are real deposit interest rate of a typical SSA country (RIR) ${ }^{10}$, real exchange rate (RXR), migrant-host country income (MGY), migrant-home country income (FMY), home-country CPI-based inflation rate (INF), bank credit to the private sector as a percentage of GDP in the home country (PSC), and institutional quality (INS). A time-dummy (DI) was introduced to capture post-September 11, 2001; such that $D 1=0$ for $1980-2001$, and $D 1=1$ for 2002-2009. The introduction of $D 1$ is also important as it helps to prevent any possible cross-individual correlation or contemporaneous correlation. $\rho$ unknown parameter of the lagged endogenous variable; $\beta$ is the unknown parameter vector of the $k$ exogenous variables; $l$ is the number of significant lags carried by the endogenous variable; and $\alpha_{i}$ individual specific fixed effects. This model is also based on the assumptions that: (i) the error term is orthogonal to the exogenous variables so that, $E\left(x_{i t}^{\prime} \varepsilon_{i t}\right)=0$; (ii) the error term (i.i.d) is uncorrelated with the lagged endogenous variable implying that $E\left(R_{i, t-1} \varepsilon_{i t}\right)=0$; and (iii) the exogenous variables might be correlated with the individual effect in which case $E\left(x_{i t}^{\prime} \alpha_{i}\right) \neq 0$.

Equation (9) also shows that there are $T-2$ orthogonality restrictions in levels which are exploited; hence observation $t$ in levels was used for the estimation, where differences are used as valid instruments, as it is assumed that $x$ is at least predetermined.

A more specific version of Equation (9) can be specified as:

$$
\begin{aligned}
R_{i, t}= & \alpha_{0}+\sum_{\rho=1}^{n} \alpha_{\rho} R_{i, t-\rho}+\alpha_{n+1} F \tilde{M} Y_{i, t}+\alpha_{n+2} M \tilde{G} Y_{i, t}+\alpha_{n+3} P S C_{i, t}+\alpha_{n+4} I N S_{i, t}+\alpha_{n+5} I N F_{i, t}+\alpha_{n+6} R X R_{i, t} \\
& +\alpha_{n+7} R I R_{i, t}+\alpha_{n+8} D 1_{i, t}+\varepsilon_{i, t}
\end{aligned}
$$

where home-country income (FMY) and host-country income (MGY) are in their natural logarithmic forms, and hence denoted as $F \tilde{M} Y$ and $M \tilde{G} Y$ respectively.

To circumvent the highly possible presence of endogeneity in the empirical model that has a panel structure of small $T$ and large $N$, the analytical approach appealed to the system GMM estimation so as to obtain efficient, reliable and unbiased estimators. It is, thus, acknowledged that the underlying relationship of the empirical model is linear; the left-hand side variable is singular and dynamic, depending on its own past realizations; the explanatory variables are not strictly exogenous; there are fixed individual effects; and there are heteroskedasticity and autocorrelation within the cross-sectional units but not across them (Behr, 2003; Roodman, 2006). The Blundell and Bond (1998) system GMM estimation technique is a preferred choice over the 'difference' GMM proposed by Arellano and Bond (1991) and 'deviation' GMM suggested by Arellano and Bover (1995) because in system GMM, it is possible to include time-invariant regressors which tend to disappear in 'difference' GMM (Roodman, 2006). Furthermore, 'difference' GMM and 'deviation' GMM are known to be inefficient when instruments are weak as they rely on information contained in differences only, but in the Blundell-Bond (1998) framework, additional relevant information besides the differences is utilized. Therefore, by allowing for more instruments, the estimated parameters of system GMM are not only more efficient, but also more consistent than other alternative techniques of dynamic panel-data analysis.

Dynamic panel-data system GMM methodological approach involves estimating a set of simultaneous equations, one in levels (with lagged first differences as instruments) and the other 
in first differences (with lagged levels as instruments). System GMM panel estimator is considered the most reliable in exploiting the initial condition in generating efficient estimators of a dynamic panel when $T$ is small relative to $N$ (Blundell and Bond, 1998). Using $y_{i t}$ as a dependent variable, Blundell and Bond (1998) prove that an additional mild stationarity restriction on the initial conditions process allows the use of an extended system GMM estimator that utilizes lagged differences of $y_{i t}$ as instruments for equations in first differences. This endowment of the system GMM estimator is very important in estimating the macroeconomic factors that influence international remittance flows to SSA since strict exogeneity of the righthand side variables rules out any possibility of feedback from the current and past shocks to the current values of the remittance flows. Normally, in the context of macroeconomic models relating to several jointly determined outcomes and in consistency with the theories underlying migrant remittance inflows, current level of remittances can be influenced by how much was remitted in the past as social ties weaken overtime (often by the second generation) resulting in remittances decreasing in value with duration of stay (Lucas and Stark, 1985; Merkle and Zimmermann, 1992; Glytsos, 1997).

To test for the joint validity of the instruments used, the Sargan-Hansen test for overidentifying restrictions was performed as suggested by Bond (2002) and Roodman (2006). The Arellano-Bond zero-correlation test was performed to be certain that there is no second-order autocorrelation in the idiosyncratic disturbance term.

\section{Data Issues}

Low frequency highly-balanced panel data from secondary sources was used in this study. The relevant annual series were collated on 36 SSA countries for the period, 1980-2009. The selection of the 36 SSA countries (listed in Table 1 above) was based strictly on data availability. In other words, the sample size was determined strictly by availability of consistent data on relevant variables, particularly migrant remittances. The key variable of focus and the variable measurement which posed the greatest challenge is migrant remittances. The choice of the start date was contingent upon the desire to cover as many countries as possible for higher representation of the population rather than covering longer periods with limited coverage of sample units.

In this paper, migrant remittances constitute the sum of workers' remittances recorded in the current account of the balance of payments under the heading "current transfers"; and compensation of employees recorded under the "income" sub-category of the current account. This implies that compensation of employees is the net of migrant remittances less workers' remittances. Details about migrant remittances and the components were obtained mainly from the 2010 World Development Indicators (WDI) published by the World Bank based on the Balance of Payments Statistics Yearbook (BoPS) of the International Monetary Fund (IMF). Other sources such as estimates based on IMF country-specific desks were used to fill in missing data where possible ${ }^{11}$.

The main explanatory variables are the traditional macroeconomic variables notably migrant-host country income, migrant-home country income, rate of inflation, exchange rate, interest rate, and private sector credit obtained essentially from the International Financial Statistics Yearbook (IFS) and World Economic Outlook (WEO), as well as the World Bank's WDI. 
The rate of inflation obtained from WDI, IFS and WEO is defined and measured as the annual percentage change in consumer price index of a typical SSA migrant-home country. Real exchange rate (RXR) is the annual average value of the national currency of a sampled SSA country in real terms of the national currency of the migrant-host country. The author computed RXR by multiplying the bilateral nominal exchange rate of a given SSA by the ratio of the hostcountry CPI to the home-country CPI based on reported data obtained from WDI, IFS and WEO. From these same sources, real deposit interest rate (RIR) was measured by the author as the average annual deposit rate of a typical SSA country minus average annual CPI-based inflation rate of the home country. Host-country income which was used to proxy migrant income is the real per capita GDP of a typical non-SSA migrant-host country ${ }^{12}$. Home-country income which was used to proxy family income is the real per capita GDP of a typical sampled SSA country. Both MGY and FMY were obtained from WDI and WEO. Domestic credit to private sector as a ratio of GDP (PSC) is the total domestic credit to the private sector by the financial system as a ratio of nominal GDP. The main sources of PSC are WDI and the Central Bank website of selected sampled SSA countries.

Institutional quality index (INS) extracted from the popular Marshall and Jaggers (2011) is the polity2 index used to capture the qualities of democratic governance and institutions in a typical SSA home-country. It ranges between -10 for low democratic governance (including dictatorship and autocratic regimes) and weak institutions and +10 for high democratic governance and strong institutions. Finally, the post-September 2011 effect on international migrant remittance flows to SSA was captured by a dummy that takes the value of zero for periods preceding 2002 and one for the years 2002 and beyond. Table A2 in the Appendix summarizes the definition and main sources of data as well as the expected empirical relationship between each of the explanatory variables and international migrant remittances.

\section{EMPIRICAL RESULTS AND DISCUSSIONS}

The findings of the study are presented in Table 2 . The results of the diagnostic tests suggest that the efficiency and reliability of the estimated parameters are not undermined by the choice of invalid instruments or second-order autocorrelation. A one percent level of statistical significance of the Wald statistics shows that the explanatory variables jointly explain the dependent variable in the models.

The results of this study suggest that, although in a contrasting manner, both homecountry and host-country macroeconomic conditions are crucial determinants of migrant remittances irrespective of duration of stay. Whereas factors relating to economic conditions in host countries, notably changing levels in host-country income, real bilateral exchange rate and law enforcement to clampdown on the use of informal money transfer channels seem to have the same effect on both category of migrants, the influence of macroeconomic conditions in the home country has a sharply contrasting impact on migrants, depending upon their duration status. For example, with a percentage rise in the income level in a host country, the amount of remittances sent by permanent migrants and temporary migrants can rise by 9.99 and 10.45 per cent respectively. Similarly, following tighter regulations of international money transfers and clampdown on the use of informal transfer channels in the aftermath of the September-11 Al Qaeda attacks, remittances from both categories of migrants increased, with a higher increase in the case of permanent migrants. Probably this is because, given their longer duration of stay, 
permanent migrants, unlike temporary migrants, might have had better insight and, hence, higher patronage of informal transfer channels in the past to avoid paying commission on funds transferred to the native countries. Real appreciation of bilateral exchange rate results in higher funds transfer from permanent as well as temporary migrants, with a relatively higher impact on remittances from temporary migrants. If it is assumed that temporary migrants are under pressure to remit at all costs because their trips were collectively funded by family members or to offset personal loans contracted prior to migration, this category of migrants will have to remit more funds (in relative terms of the host-country currency) when exchange rate appreciates, in order to settle the target recipients at home with the same value (in the home-country currency) of regular 'installment' or remittance mutually agreed on by parties in the implicit contract.

\section{TABLE 2. ESTIMATED RESULTS OF WORKERS' REMITTANCES AND COMPENSATION OF EMPLOYEES}

Group variable: ccode

Number of groups $=36$

Time variable: year

Observation per group $=26$

\begin{tabular}{|c|c|c|}
\hline \multicolumn{3}{|c|}{ Two-Step Estimation by Blundell-Bond System Dynamic Panel-Data Procedure } \\
\hline & WREMPC & COMPPC \\
\hline$R_{-1}$ & $\begin{array}{l}0.97563 \\
(288.79)^{* * *}\end{array}$ & $\begin{array}{l}0.87029 \\
(946.77)^{* * *}\end{array}$ \\
\hline$R_{-2}$ & $\begin{array}{l}-0.13008 \\
(-60.31)^{* * *}\end{array}$ & $\begin{array}{l}-0.03179 \\
(-30.00)^{* * *}\end{array}$ \\
\hline Institutional quality & $\begin{array}{l}-0.83482 \\
(-17.34)^{* * *}\end{array}$ & $\begin{array}{l}0.34857 \\
(18.34)^{\text {*** }}\end{array}$ \\
\hline Home-country income & $\begin{array}{l}1.16050 \\
(1.72)^{*}\end{array}$ & $\begin{array}{l}-4.50763 \\
(-31.63)^{* * *}\end{array}$ \\
\hline Host-country income & $\begin{array}{l}9.99314 \\
(7.82)^{* * *}\end{array}$ & $\begin{array}{l}10.44932 \\
(26.92)^{* * *}\end{array}$ \\
\hline Rate of inflation & $\begin{array}{l}0.01080 \\
(0.49)\end{array}$ & $\begin{array}{l}0.07092 \\
(5.83)^{* * *}\end{array}$ \\
\hline Bank credit to private sector & $\begin{array}{l}0.13479 \\
(8.26)^{* * * *}\end{array}$ & $\begin{array}{l}-0.15802 \\
(-28.38)^{* * *}\end{array}$ \\
\hline Real deposit interest rate & $\begin{array}{l}0.00501 \\
(0.23)\end{array}$ & $\begin{array}{l}0.08850 \\
(6.82)^{* * * *}\end{array}$ \\
\hline Real exchange rate & $\begin{array}{l}-0.00029 \\
(-1.78)^{*}\end{array}$ & $\begin{array}{l}-0.00252 \\
(-4.62)^{* * *}\end{array}$ \\
\hline Dummy for September 11, 2001 & $\begin{array}{l}5.41298 \\
(54.32)^{* * *}\end{array}$ & $\begin{array}{l}2.03112 \\
(31.09)^{\text {**** }}\end{array}$ \\
\hline Constant term & $\begin{array}{l}-105.033 \\
(-12.18)^{* * *}\end{array}$ & $\begin{array}{l}-69.7911 \\
(-16.25)^{* * *}\end{array}$ \\
\hline \multirow{2}{*}{$\begin{array}{l}\text { Number of instruments } \\
\text { Number of observations } \\
\text { Wald } \chi^{2}(\bullet)\end{array}$} & $\begin{array}{l}442 \\
1003\end{array}$ & $\begin{array}{l}442 \\
1003\end{array}$ \\
\hline & $609000^{* * *}$ & $2250000^{* * *}$ \\
\hline \multicolumn{3}{|c|}{ Arellano-Bond test for zero autocorrelation in first-difference errors (order 2): } \\
\hline \multicolumn{3}{|c|}{ Sargan-Hansen test of over-identifying restrictions: } \\
\hline$\chi^{2}(\bullet)$ & $28.57\{0.99\}$ & $33.79\{0.99\}$ \\
\hline
\end{tabular}

Source: Author's estimation.

Note: ${ }^{*} I^{* * *}$ indicates significant at 10 percent and 1 percent respectively. 
Concerning home-country economic conditions, whereas permanent migrants are only likely to remit more when income levels at home improve as consistent with the self-interest portfolio motive, temporary migrants are likely to remit more when economic conditions at home deteriorate. A percentage rise in home-country income levels induces permanent migrants to increase amounts remitted by 1.1605 percent only at 10 percent level of statistical significance. However, temporary migrants are inclined to increase amounts remitted by 4.5076 percent should home-country income decrease by one percent. One possible reason is that permanent migrants are more likely to have 'insured' their families against negative economic shocks at home through past remittances or these permanent migrants might have been joined by their closest dependants in the host-country, having acquired legal residential status. This reduces the migrant's direct responsibilities to those at home and is in contrast with the situation of newly arrived migrants.

When governance and political conditions at home improve by one unit, temporary migrants are motivated to increase amounts remitted by 0.34857 units, but official remittances from permanent migrants are likely to reduce by 0.83482 . This is probably because, unlike permanent migrants, temporary migrants being more altruistic-driven (a reason why they remit more as home-country income falls and home-country inflation rises), are regular remitters even when general socioeconomic conditions at home deteriorate. However, because permanent migrants are unlikely to be regular remitters as social ties become weaker between them and their families back home as duration of stay abroad increases, they are likely to remit more when political conditions at home deteriorate. Probably, some of these permanent migrants are encouraged to increase the amount they remit during because of economic or political interest or other personal ambitions. With a higher real deposit rate, temporary migrants are likely to remit more, probably because they are more likely to return home in the near future and hence they need funds to finance entrepreneurial ventures upon return. Just like inflation, a rise in the real deposit interest rate of the home-country has no effect on the amount of remittances sent by permanent migrants. With improved access to the bank credit of family members back home, permanent migrants remit more, probably for self-interest portfolio motives; but temporary migrants remit more to lessen the liquidity constraints of those left behind when access to bank credit becomes more limited at home.

\section{CONCLUSIONS, POLICY IMPLICATIONS AND RECOMMENDATIONS}

Based on the empirical results, it can be concluded that over the past three decades, remittances from permanent migrants have been the dominant component of total migrant remittances received in SSA. Remittances from temporary migrants are relatively more altruistically driven whereas those from permanent migrants are more self-interest or investment driven. To this extent, as far as remittances are concerned, migrants react differently to macroeconomic conditions at home depending upon their duration of stay. This implies that generally initial remittances are essentially altruistic. Overtime, remittances tend to be driven by self-interest economic motive. However, because altruism is inherent in all other motives of remittances and other motives of remittances only become important after altruism, a labor-exporting SSA country will receive more remittances on a permanent basis if there is a stable and investmentfriendly macroeconomic environment. In other words, given a sound macroeconomic 
environment, a typical labor-exporting SSA country can receive higher remittances in excess of pure altruism more permanently.

The findings imply that policymakers in SSA should not be deceived into thinking that they can attract higher remittances from permanent migrants without implementing stable and pro-growth economic policies. Needless to say, SSA is the sub-region that receives the least migrant remittances through official channels due to lack of an appropriate macroeconomic policy environment. It is, therefore, recommended that policymakers in SSA should devise strategies aimed at achieving a lower rate of inflation, higher and sustained rate of economic growth, improved financial market development and exchange rate stability in order to attract higher remittances from permanent migrants who sent over 90 percent of total migrant remittances received in the sub-region between 1980 and 2009.

\section{ENDNOTES}

${ }^{1}$ Developing countries receive at least 75 percent of reported migrant remittances. In 2009, developing countries alone received as much as US $\$ 316$ billion out of the world's total of US\$414 billion, representing 76.3 percent even though the amount they received in 2009 fell by about 6 percent of the amount they received in 2008 (Author's computation based on World Bank (2010).

${ }^{2}$ Migrant remittances are the second largest form of non-debt capital inflows in developing countries. In the Middle East and North Africa just as in South Asia, it is now the leading source of external capital (see Figure A1 in Appendix).

${ }^{3}$ It is well-known in the remittance literature that official remittances represent an underestimation of the total remittances received in developing countries as at least 50 percent of remittances (what is official reported) are sent through unofficial channels.

${ }^{4}$ This confirms earlier estimates by Ratha and Shaw (2007). For Africa as a whole, Barajas et al. (2010) observe that more than 50 percent of African migrants reside in other African countries.

${ }^{5}$ Sander and Maimbo (2003) and Barajas et al. (2010) also identify Europe rather than North America as the main host of African migrants.

${ }^{6}$ This is in line with the Lewis (1954) theory of excess supply of labor, resulting in high unemployment and low wages in underdeveloped economies, which forces the nationals of these underdeveloped economies to migrate to the industrialised world where there is a higher prospect of being engaged in relatively higher income jobs.

${ }^{7}$ A migrant's determination to save part of his/her disposable income may also be applicable in this context if he/she is aiming at sponsoring a family member in his/her home country to travel abroad. A rational migrant's motivation to save can also be driven by his/her motivation to hedge against negative income shocks in his/her host country.

${ }^{8}$ In this case $U_{1}$ is the derivative of utility with respect to home-country consumption.

${ }^{9}$ According to Vargas-Silva and Huang (2006: 86), "similar results can be obtained assuming that, in the second period, the migrant returns to the home country and joins the household".

${ }^{10}$ It was not possible to use real interest rate differential due to data constraints on migrant host countries. Apart from France, none of the migrant host nations has a complete data on deposit interest rates. For instance, there are no reported data on Germany, Portugal and Great Britain beyond 1999. Belgium and Spain have no reported data on deposit interest rates beyond the year 2003 whilst for Pakistan and Saudi Arabia, data is non-existent for the years 1980-2003 and 1980-87. USA does not report deposit interest rates at all for the entire study period.

${ }^{11}$ In a recent study, Singh et al. (2010) used a similar approach to obtain remittances data on 36 SSA countries.

12 A single non-SSA migrant-host country rather than say the top-5 migrant-host countries was used because this helps to minimize the often illogical statistical reasoning and fundamental errors often associated with aggregation and determination of weights for the computation of real exchange rates and real per capita income of migrants especially when these countries are not necessarily the major trading partners of SSA countries. The choice of a single non-SSA host country has also helped to reduce the occurrence of missing data that had the potential of limiting the scope of this study. 


\section{APPENDIX}

FIGURE A1. TRENDS IN EXTERNAL CAPITAL FLOWS TO DEVELOPING ECONOMIES, 1970-2009
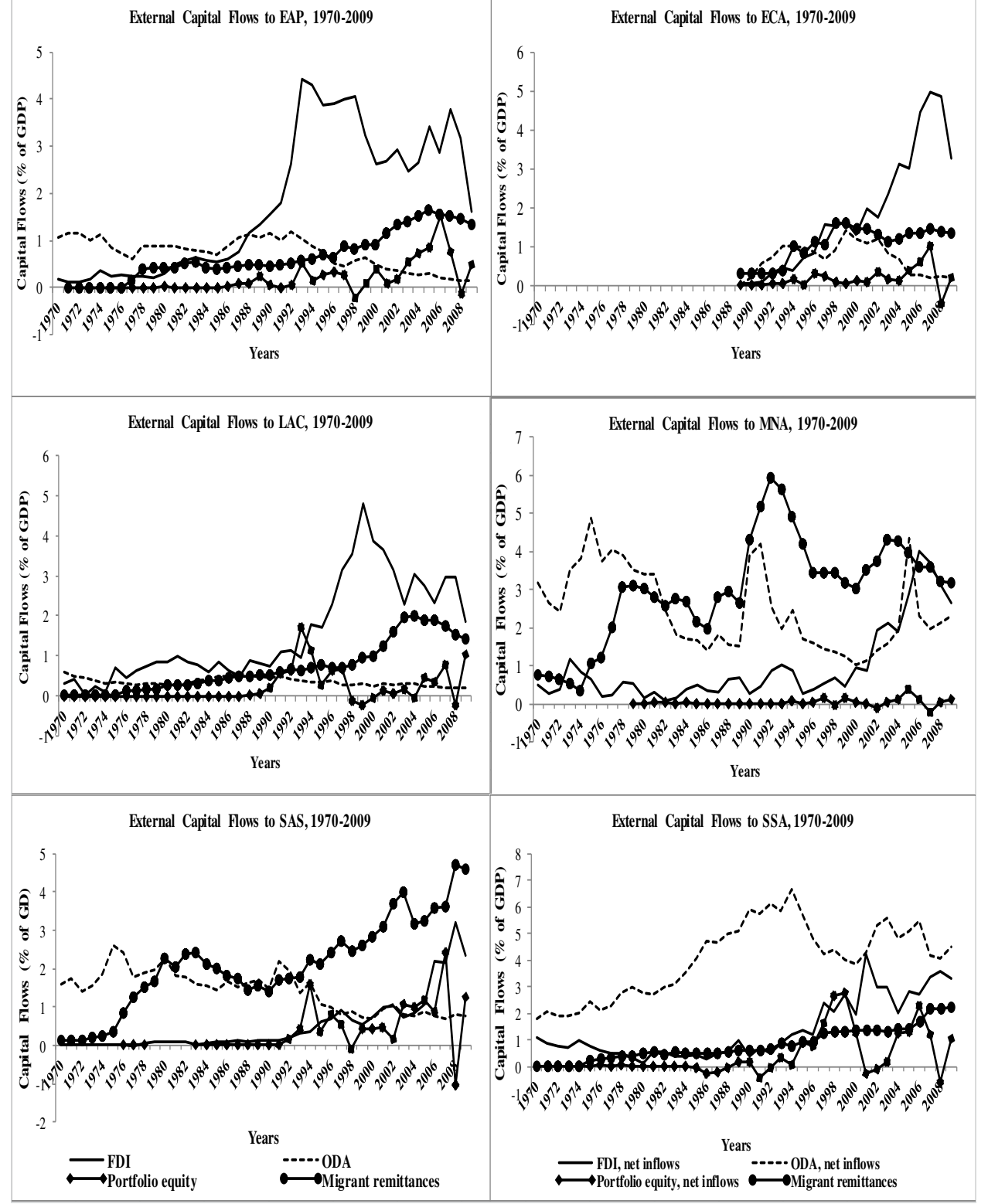

Source: Author based on World Bank (2010).

Note: EAP, ECA, LAC, MNA, SAS and SSA denote East Asia and Pacific, Europe and Central Asia, Latin America and the Caribbean, Middle East and North Africa, South Asia, and Sub-Saharan Africa respectively. 
FIGURE A2. TRENDS IN MIGRANT REMITTANCE FLOWS TO DEVELOPING ECONOMIES, 19702009

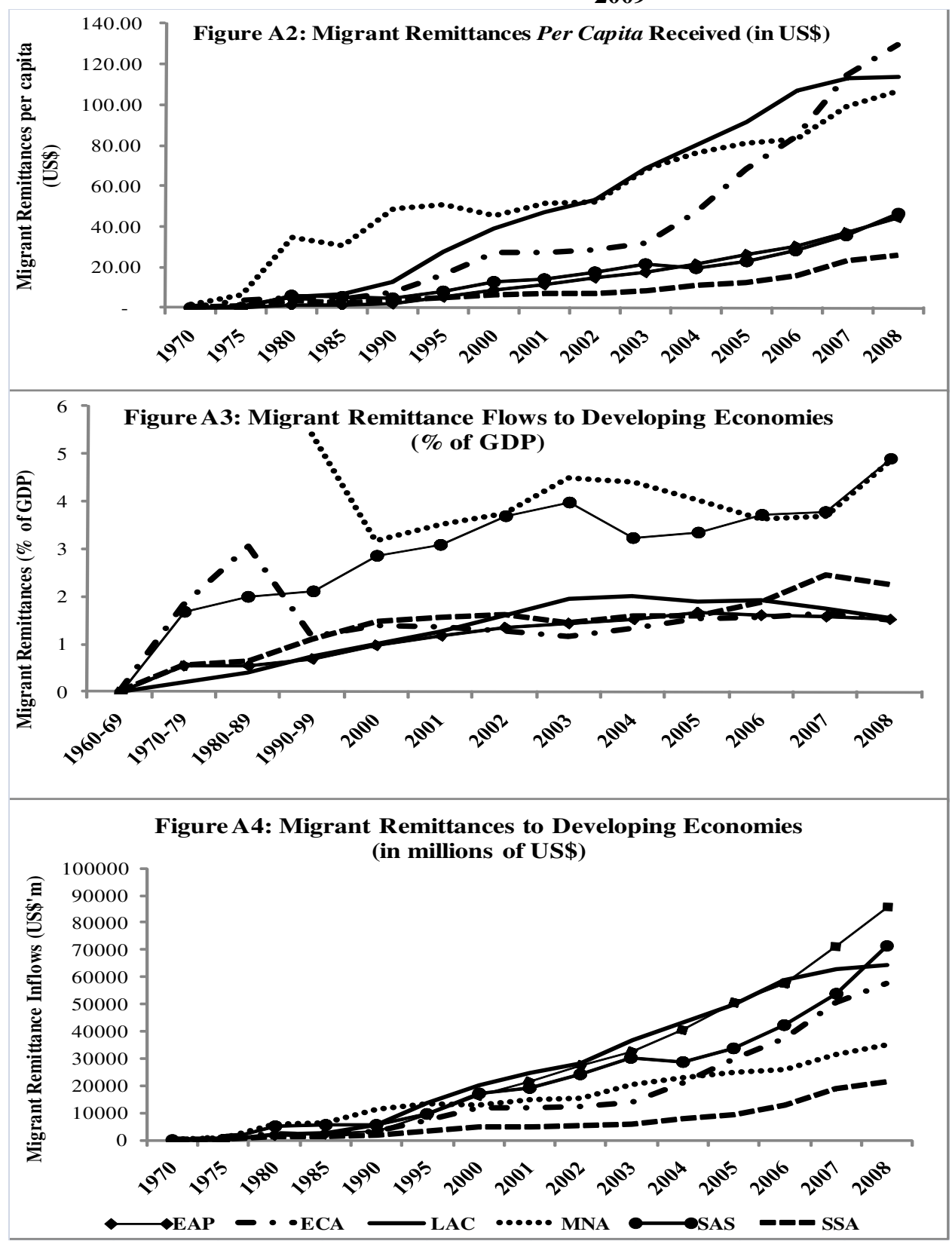

Source: Author based on World Bank (2010).

Note: EAP, ECA, LAC, MNA, SAS and SSA denote East Asia and Pacific, Europe and Central Asia, Latin America and the Caribbean, Middle East and North Africa, South Asia, and Sub-Saharan Africa respectively. 


\section{TABLE A1. HOST COUNTRIES OF SSA MIGRANTS}

\begin{tabular}{|c|c|c|c|c|c|c|c|c|}
\hline \multirow[b]{2}{*}{ Migrant Home-Country } & \multicolumn{5}{|c|}{ Top-5 SSA Migrant Host Countries in the World } & \multicolumn{3}{|c|}{ Top-3 Non-SS A Host Countries } \\
\hline & 1 & 2 & 3 & 4 & 5 & 1: Host & 2 & 3 \\
\hline Benin (BEN) & NIG (27.71) & BFA (12.68) & TOG (12.45) & CIV (10.60) & GAB (5.59) & $\operatorname{FRA}(2.22)$ & GER (1.30) & PAK (1.07) \\
\hline otswana (BSW) & RSA (18.01) & NAM (16.96) & $\operatorname{GBR}(12.47)$ & ZIM (11.64) & USA (9.58) & $\mathrm{BR}(12.47)$ & USA (9.58) & $\operatorname{AUS}(4.27)$ \\
\hline Burkina Faso (BFA) & CIV (72.47) & GUI (11.03) & GHA (5.13) & $\operatorname{DRC}(1.38)$ & $\operatorname{PAK}(1.06)$ & $\operatorname{PAK}(1.06)$ & GER (1.03) & FRA (0.37) \\
\hline Cameroon (CAM) & FRA (22.62) & GAB (17.74) & NIG (9.91) & USA (7.53) & GER (5.43) & $\operatorname{FRA}(22.62)$ & USA (7.53) & GER (5.43) \\
\hline ape Verde (CPV) & POR (22.52) & SA (13.83) & FRA (6.65) & GER (6.61) & MZQ (8.44) & $\operatorname{POR}(22.62)$ & USA (13.83) & FRA (6.65) \\
\hline omoros (COM) & FRA (43.14) & UGA (22.47) & GER (7.01) & TZA (4.68) & $\operatorname{LBY}(2.59)$ & FRA (43.14) & GER (7.01) & USA $(0.50)$ \\
\hline Congo Republic (CON) & SUD (47.91) & TZA (16.03) & FRA (8.34) & BEL (2.68) & GER (2.29) & FRA $(8.34)$ & $\operatorname{BEL}(2.68)$ & $\operatorname{GER}(2.29)$ \\
\hline Côte d'Ivoire (CIV) & FRA (27.38) & BFA (19.72) & GER (5.95) & $\operatorname{BEN}(6.56)$ & GUI (5.40) & FRA (27.38) & GER (5.95) & USA (4.57) \\
\hline hiopia (ETH) & USA (25.65) & $67)$ & SAU (7.72) & CAN (5.08) & SWE (3.40) & $A(25.65)$ & ISR (20.67) & (7.72) \\
\hline Gabon (GAB) & SUD (47.30) & FRA (19.69) & SLE (4.39) & GER (3.44) & KEN (3.66) & FRA (19.69) & GER (3.44) & USA $(0.92)$ \\
\hline Gambia (GAM) & $\operatorname{ESP}(12.18)$ & USA (11.95) & NIG (8.45) & 7.73) & $\operatorname{SEN}(3.67)$ & $\operatorname{ESP}(12.18)$ & USA (11.95) & GBR (7.73) \\
\hline inana (GHA) & CIV (31.91) & NIG (13.06) & BFA (9.74) & GUI (8.69) & USA (7.31) & $\operatorname{USA}(7.31)$ & $\operatorname{GBR}(5.97)$ & $\operatorname{GER}(2.27)$ \\
\hline Suinea (GUI) & CIV (23.74) & LIB (12.11) & SEN (18.69) & BFA (11.17) & GAM (6.57) & GBR (1.45) & GER (1.34) & USA (1.15) \\
\hline uinea-Bissau & SEN (25.45) & GAM (13.36) & POR (16.72) & FRA (6.34) & BFA (5.81) & $\mathrm{OR}(16.72)$ & FRA (6.34) & GER (4.45) \\
\hline Kenya (KEN) & GBR (28.54) & TZA (27.04) & UGA (7.35) & USA (9.85) & GER (5.38) & GBR (28.54) & USA (9.85) & GER (5.38) \\
\hline Lesotho (LSO) & MZQ (46.02) & ZIM (19.45) & RSA (16.18) & MWI (2.38) & TZA (1.72) & $\operatorname{GER}(0.82)$ & USA $(0.81)$ & $\operatorname{PAK}(0.71)$ \\
\hline Madagascar (MAD) & FRA (51.55) & REU (12.88) & GER (8.64) & ZIM (4.22) & $\mathrm{COM}(3.82)$ & FRA (51.55) & REU (12.88) & GER (8.64) \\
\hline Malawi (MWI) & ZAM & $\mathrm{TZ}$ & ) & ZIM (12.91) & ) & 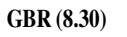 & 3) & 8) \\
\hline Mali (MLI) & CIV (30.82) & BFA (27.74) & GUI (10.32) & NIG (5.77) & GHA (5.22) & $\operatorname{FRA}(2.73)$ & GER (1.37) & USA $(0.45)$ \\
\hline Mauritania & SEN (34.21) & NIG (10.32) & FRA (8.78) & BFA (7.68) & GUI (7.56) & FRA $(8.78)$ & $\operatorname{ESP}(3.21)$ & $\operatorname{GER}(2.72)$ \\
\hline Mauritius (MRS) & FRA (18.41) & RSA (18.39) & GBR (15.63) & AUS (9.70) & GER (6.53) & FRA (18.41) & GBR (15.63) & $\operatorname{AUS}(9.70)$ \\
\hline Iozambique (MZQ) & TZA (22.78) & ZIM (19.98) & MWI (19.16) & RSA (17.74) & POR (8.97) & $\operatorname{POR}(8.97)$ & GER (2.07) & $\operatorname{GBR}(0.50)$ \\
\hline Namibia (NAM) & MZQ (23.07) & RSA (17.28) & ZIM (13.13) & TZA $(1.50)$ & GBR (5.14) & GBR (5.14) & USA (4.19) & GER (1.88) \\
\hline Niger (NGR) & BFA (27.84) & CIV (26.25) & NIG (11.89) & GUI (10.79) & GHA (5.16) & GER (1.10) & PAK (1.06) & FRA $(0.73)$ \\
\hline Nigeria (NIG) & SUD (23.76) & USA (13.74) & GBR (8.60) & CAM (8.39) & GHA (5.14) & USA (13.74) & GBR (8.60) & GER (2.91) \\
\hline wanda (RWA) & GA (42.17) & TZA (27.94) & KEN (4.89) & 3EL (2.83) & GER & ) & 7) & 6) \\
\hline São Tomé \& Príncipe & POR (54.97) & CPV (15.94) & GER $(9.30)$ & BFA (3.00) & GUI (2.93) & POR (54.97) & GER (9.30) & FRA (1.02) \\
\hline Senegal (SEN) & GAM (20.56) & FRA (18.32) & ITA $(9.58)$ & MRT (8.48) & GER (5.30) & FRA (18.32) & ITA $(9.58)$ & GER (5.30) \\
\hline Seychelles (SEY) & GBR (17.40) & RSA (18.69) & AUS (14.55) & ZIM (6.24) & TZA (6.18) & $\operatorname{GBR}(17.40)$ & $\operatorname{AUS}(14.55)$ & CAN (6.15) \\
\hline Sierra Leone (SLE) & USA (22.87) & LIB (18.31) & GBR (18.18) & GHA (5.00) & GER (4.50) & USA (22.87) & GBR (18.18) & GER (4.50) \\
\hline South Africa (RSA) & GBR (18.15) & MZQ (16.04) & AUS (10.12) & USA (8.99) & ZIM (7.37) & GBR (18.15) & $\operatorname{AUS}(10.12)$ & USA (8.99) \\
\hline Sudan (SUD) & SAU (32.05) & UGA (24.31) & JOR (3.78) & USA (3.43) & EGY (2.64) & $\mathrm{SAU}(32.05)$ & JOR (3.78) & USA (3.43) \\
\hline Swaziland (SWZ) & MZQ (28.48) & RSA (17.05) & ZIM (14.53) & GBR (7.43) & USA (5.46) & GBR (7.43) & USA (5.46) & GER (2.30) \\
\hline Tanzania (TNZ) & UGA (20.46) & RSA (18.31) & GBR (11.48) & ZIM (8.81) & CAN (6.95) & GBR (11.48) & CAN (6.95) & USA (4.47) \\
\hline Togo (TOG) & NIG (36.10) & BEN (12.05) & BFA (8.75) & GUI & GAM (6.61) & FRA (6.38) & GER (2.02) & USA (1.63) \\
\hline Uganda (UGA) & GBR (32.41) & TZA (23.82) & USA (7.38) & CAN (6.48) & GER (6.06) & GBR (32.41) & USA (7.38) & CAN (6.48) \\
\hline
\end{tabular}

Source: Author's compilation from Parson et al. (2007).

Note: AUS, CAN, ISR, ITA, LIB, DRC, EGY, REU, SWE, ZAM, ZIM, JOR, and LBY stand for Australia, Canada, Israel, Italy, Liberia, Democratic Republic of Congo, Egypt, Reunion, Sweden, Zambia, Zimbabwe, Jordan and Libya respectively. 


\begin{tabular}{|c|c|c|}
\hline & TABLE & MEASUREMENT AND SOURCES \\
\hline Variable & Notation & Description, Measurement and Main Sources \\
\hline Dependent Variable & & \\
\hline Workers' & WREMPC & Remittances sent by SSA migrants who spent at least 12 months in a host country. Source: \\
\hline $\begin{array}{l}\text { remittances per } \\
\text { capita }\end{array}$ & & 2010 Editions of $W D I, B o P S$ and estimates from IMF country-desks as at February 9, 2011. \\
\hline $\begin{array}{l}\text { Compensation of } \\
\text { employees per } \\
\text { capita }\end{array}$ & COMPPC & $\begin{array}{l}\text { Remittances sent by SSA migrants who spent less than } 12 \text { month in a host country. Source: } \\
\text { Author's computation based on reported data in WDI, BoPS and estimates from country- } \\
\text { desks information at IMF. }\end{array}$ \\
\hline Explanatory Variab & & \\
\hline Lagged dependent & $R_{-1,2}^{+,-/ 0}$ & $\begin{array}{l}\text { The immediate two past values of the dependent variable. In this case, } R \text { represents in the } \\
\text { respective WREMPC and COMPPC estimated models. Source: Author's computation. }\end{array}$ \\
\hline Inflation rate & $I N F^{+/-}$ & $\begin{array}{l}\text { Rate of growth in annual average consumer price index. Source: WDI, IMF's International } \\
\text { Financial Statistics (IFS), and WEO }\end{array}$ \\
\hline $\begin{array}{l}\text { Real exchange } \\
\text { rate }\end{array}$ & $R X R^{+/-}$ & $\begin{array}{l}\text { The annual average value of the national currency of a sampled SSA country in real terms } \\
\text { of the national currency of the migrant-host country. Source: Author's computation based } \\
\text { on data from WDI, IFS and WEO. }\end{array}$ \\
\hline $\begin{array}{l}\text { Host-country } \\
\text { income }\end{array}$ & $M G Y^{+}$ & Real per capita GDP of a typical non-SSA migrant host country. Source: WDI and WEO. \\
\hline $\begin{array}{l}\text { Home-country } \\
\text { income }\end{array}$ & $F M Y$ & Real per capita GDP of a typical SSA country. Source: WDI and WEO. \\
\hline Deposit & & Average annual deposit rate of a typical SSA country minus average annual CPI-based \\
\hline Interest Rate & $R I R^{+/ 0}$ & $\begin{array}{l}\text { inflation rate. Source: Author based on WDI, IFS, WEO and Central Banks of selected } \\
\text { countries. }\end{array}$ \\
\hline $\begin{array}{l}\text { Domestic credit to } \\
\text { private sector as } \\
\text { ratio of GDP }\end{array}$ & $\mathrm{PSC}^{+/-}$ & $\begin{array}{l}\text { Total domestic credit to the private sector by the financial system as a ratio of GDP. Source: } \\
\text { WDI and the Central Bank website of selected sampled countries. }\end{array}$ \\
\hline $\begin{array}{l}\text { Institutional } \\
\text { quality index }\end{array}$ & $I N S^{+/-}$ & $\begin{array}{l}\text { A polity } 2 \text { index used to capture the qualities of democratic governance and institutions in a } \\
\text { typical home SSA country. It ranges between }-10 \text { for low democratic governance (including } \\
\text { dictatorship and autocratic regimes) and weak institutions, and }+10 \text { for high democratic } \\
\text { governance and strong institutions. Source: Marshall and Jaggers }(2011)\end{array}$ \\
\hline $\begin{array}{l}\text { Post-September } \\
11,2001\end{array}$ & $D 1^{+}$ & $\begin{array}{l}\text { A dummy to capture post-September } 11,2001 \text {, when the US and other migrant-host } \\
\text { countries improved regulations on international money transfers, which has discouraged } \\
\text { migrants from using informal channels to remit. Source: Author's construction. }\end{array}$ \\
\hline
\end{tabular}

Source: Author.

Note: The a priori sign is indicated by ${ }^{+/ / 0}$ by the notation column of each variable. 


\section{REFERENCES}

Adenutsi, Deodat E., Meshach J. Aziakpono and Matthew K. Ocran (2011). "The Changing Impact of Macroeconomic Environment on Remittance Inflows in Sub-Saharan Africa," Journal of Academic Research in Economics, Vol. 3, No. 2, pp. 136-167.

Adenutsi, Deodat E., Meshach J. Aziakpono and Matthew K. Ocran (2012). "Macroeconomic Environment and Remittances in Post-Independent Sub-Saharan Africa: Magnitudes, Trends and Stylized Facts," Studies in Economics and Econometrics, Vol. 36, No. 2, pp. 1-22.

Arellano, Manuel and Stephen Bond (1991). "Some Tests of Specification for Panel Data: Monte Carlo Evidence and an Application to Employment Equations," Review of Economic Studies, Vol. 58, No. 2, pp. 277-297.

Arellano, Manuel and Olympia Bover (1995). "Another Look at the Instrumental Variable Estimation of Error-Components Models," Journal of Econometrics, Vol. 68, No. 1, pp. 29-51

Aydaş, Osman T., Bilin Neyapti and Kivilcim Metin-Özcan (2004). "Determinants of Workers' Remittances: The Case of Turkey", Department of Economics Working Paper 0405. Ankara: Bilkent University.

Barajas, Adolfo, Ralph Chami, Connel Fullenkamp and Anjali Garg (2010). "The Global Financial Crisis and Workers' Remittances to Africa: What is the Damage?" IMF Working Paper 10/24. Washington, DC: The International Monetary Fund.

Blundell, Richard W. and Stephen Bond (1998). "Initial Conditions and Moment Restrictions in Dynamic Panel Data Models," Journal of Econometrics, Vol. 87, No. 1, pp. 115-143.

Bollard, Albert, David McKenzie and Melanie Morten (2010). "The Remitting Patterns of African Migrants in the OECD," Policy Research Working Paper 5260, Washington, D.C.: The World Bank.

Bond, Stephen (2002). "Dynamic Panel Data Models: A Guide to Micro Data Methods and Practice," Cemmap Working Paper CWP 09/02. London: The Institute for Fiscal Studies, Centre for Microdata Methods and Practice.

Bouhga-Hagbe, Jacques (2004). "A Theory of Workers' Remittances with an Application to Morocco," IMF Working Paper 04/194. Washington, DC: The International Monetary Fund.

Bouhga-Hagbe, Jacques (2006). “Altruism and Workers' Remittances: Evidence from Selected Countries in the Middle East and Central Asia," IMF Working Paper 06/130. Washington, DC: International Monetary Fund.

Brown, Richard P.C. (1997). "Estimating Remittance Functions for Pacific Migrants," World Development, Vol. 25, No. 4, pp. 613-626. 
Coulibaly, Dramane (2009). "Macroeconomic Determinants of Migrants' Remittances: New Evidence from a Panel VAR", CES Working Paper 2009.07. Paris: Centre d'Economie de la Sorbonne.

Elbadawi, Ibrahim A. and Roberto de Rezend Rocha (1992) "Determinants of Expatriate Workers' Remittances in North Africa and Europe," World Bank Policy Research Working Paper Series 1038. Washington, DC: The World Bank.

El-Sakka, Mohammed I.T. and Robert McNabb (1999) "The Macroeconomic Determinants of Emigrant Remittances," World Development, Vol. 27, No. 8, pp. 1493-1502.

Freund, Caroline and Nikola Spatafora (2005). "Remittances: Transaction Costs, Determinants, and Informal Flows," World Bank Policy Research Working Paper, Vol. 3704(September), pp. 1-42. Washington, DC: The World Bank.

Glytsos, Nicholas P. (1997). "Remitting Behavior of "Temporary" and "Permanent" Migrants: The Case of Greeks in Germany and Australia," Labor, Vol. 11, Iss. 3, pp. 409-435.

Gupta, Poonam (2005). "Macroeconomic Determinants of Remittances: Evidence from India," IMF Working Paper 05/224. Washington, DC: The International Monetary Fund.

Hansen, Lars P. (1982). "Large Sample Properties of Generalized Method of Moments Estimators," Econometrica, Vol. 50, No. 3, pp. 1029-1054.

Higgins, Matthew L., Alketa Hysenbegasi and Susan Pozo (2004). "Exchange Rate Uncertainty and Workers' Remittances," Applied Financial Economics, Vol. 14, No. 6, pp. 403-411.

Lewis, Arthur W. (1954). "Economic Development with Unlimited Supplies of Labor," Manchester School of Economic and Social Studies, Vol. 22(May), pp. 139-191.

Lianos, Theodore P. (1997) "Factors Determining Migrant Remittances: The case of Greece," International Migration Review, Vol. 31, No. 1, pp. 72-87.

Lucas, Robert E.B. and Oded Stark (1985). "Motivations to Remit: Evidence from Botswana," Journal of Political Economy, Vol. 93, No. 5, pp. 901-918.

Marshall, Monty G. and Keith Jaggers (2011). Polity IV Project: Political Regime Characteristics and Transitions, 1800-2009, Societal-Systems Research Inc. and Colorado State University.

Merkle, Lucie and Klaus Zimmermann (1992). "Savings, Remittances, and Return Migration," Economics Letters, Vol. 38, No. 5, pp. 77-81. 
Parsons, C.R., R. Skelden, T. Walmsey and L.A. Winters (2007). "Quantifying International Migration: A Database of Bilateral Migration Stocks" in Çaglar Özden and Maurice Schiff (eds.), International Migration, Economic Development, and Policy, Palgrave Macmillan and World Bank.

Ratha, Dilip and William Shaw (2007). "South-South Migration and Remittances," World Bank Development Prospects Group Working Paper 102. Washington, DC: The World Bank.

Roodman, David (2006). "How to Do xtabond2: An Introduction to "Difference" and "System" GMM in Stata, Centre for Global Development Working Paper 103(December) Washington, D.C.: Centre for Global Development.

Russell, Sharon S. (1986). "Remittances from International Migration: A Review in Perspective," World Development, Vol. 14(June), pp. 677-696.

Sander, Cerstin and Samuel M. Maimbo (2003). "Migrant Labor Remittances in Africa: Reducing Obstacles to Developmental Contributions," Africa Region Working Paper Series 64. Washington, DC: The World Bank.

Sargan, Thomas J. (1958). "The Estimation of Economic Relationships Using Instrumental Variables," Econometrica, Vol. 26, No. 3, pp. 393-415.

Sayan, Serdar (2006). "Business Cycles and Workers' Remittances: How do Migrant Workers Respond to Cyclical Movements of GDP at Home?" IMF Working Paper 06/52. Washington, DC: The International Monetary Fund.

Schrooten, Mechthild (2005). "Bringing Home the Money: What Determines Remittances to Transition Countries?” Discussion Paper Series A-466. Tokyo: Institute of Economic Research.

Singh, Raju J., Markus Haacker, Kyung-woo Lee, and Maëlan Le Goff (2010). "Determinants and Macroeconomic Impact of Remittances in Sub-Saharan Africa," Journal of African Economies, Vol. 20, No. 3, pp. 312-340.

Swamy, Gurushri (1981). "International Migrant Workers' Remittances: Issues and Prospects," World Bank Staff Working Paper 481. Washington, DC: The World Bank.

United Nations (2009). Human Development Report 2009: Overcoming Barriers -Human Mobility and Development. New York: United Nations Development Programme.

United Nations (2010) Human Development Report 2010: The Real Wealth of Nations Pathways to Human Development. New York: United Nations Development Programme.

Vargas-Silva, Carlos and Peng Huang (2006). "Macroeconomic Determinants of Workers' Remittances: Host vs. Home Country's Economic Conditions," Journal of International Trade and Economic Development, Vol. 15, No.1, pp. 81-99. 
Wahba, Sadek (1991) "What Determines Workers' Remittances?" Finance and Development, Vol. 28, No. 4, pp. 41-44.

World Bank (2006). Global Economic Prospects: Economic Implications and Migration. Washington, DC: The World Bank.

World Bank (2010). World Development Indicators, October 2010 Edition. Washington, DC: The World Bank.

Yang, Dean and HwaJung Choi (2007). "Are Remittances Insurance? Evidence from Rainfall Shocks in the Philippines", World Bank Economic Review, Vol. 21, No. 2, pp. 219-248. 